\title{
Before and after the "Treaty of Eternal Friendship." Musical and cultural contacts between Bulgaria and Yugoslavia in the 1930s (an attempt at typology)
}

\author{
Stefanka Georgieva
}

In the complicated and contradictory development of the relations between Bulgaria and Yugoslavia, the 1930s are a period which has steadily drawn the attention of Bulgarian historians. Researchers' interest in this topic has never faded, even during the Cold War, which brought the revelation and publishing of valuable documents from the accessible records of the Bulgarian Academy of Sciences and the Central State Archives in Sofia, from the Archives of Yugoslavia, press materials and others. The exploration of these enormous amounts of historiographic information is a serious trial for any attempt at suggesting a new interpretation of the events of this decade, which are only a tiny fragment of diverging and sometimes mutually exclusive tendencies in the two states' relations, heavily burdened by the consequences of the two Balkan Wars and WWI. In parallel with this, this same period was marked by an unmatched culmination in the history of their relations - the signing of the Treaty of Inviolable Peace and Eternal Friendship (1937), giving an impetus to overcome the status quo and the stagnation, mutual distrust and feud. ${ }^{1}$

The musical and cultural contacts between Bulgaria and Yugoslavia fall into the web of these complicated political processes. This paper aims to follow the dynamics of traditional connections and the establishing of new ones in the context of the resumed political dialogue between the two countries. Based on materials from the periodical press, archival sources and diplomatic correspondence related to the topic, it is an attempt to shed light on their development in order to emphasize the succession and continuity of cultural collaboration, with the participation of distinguished musicians and performers from both countries. The chronological lines of the chosen period are conditional. On the one hand, the tendency of rapprochement through choral exchange remained steady, and on the other, the

1 Krastyo Manchev, Valerian Bistritski, Bulgaria i neynite sasedi (1931-1939). Politicheski i diplomaticheski otnoshenia [Bulgaria and Its Neighbors (1931-1939). Political and Diplomatic Relations] (Sofia: Nauka i izkustvo, 1978), 63-83. 
scope of cooperation expanded through initiatives influenced to different extents by the positive tone in political communication.

Thus, a long-suppressed post-WWI process began to manifest itself as early as the mid-1920s, reviving the long cultural traditions with different centers of the new Kingdom of Serbs, Croats and Slovenes / Yugoslavia-Belgrade, Zagreb and Ljubljana. In March 1929, Belgrade's semiofficial mouthpiece Politika announced "the first mutual visits of cultural figures from both countries." 2 Quite some time before that, however, it had become popular in the Bulgarian and Yugoslav musical press to make initiatives for cooperation between professional music organizations of both countries, publishing reviews of mutual choir visits, as well as information about events in musical life and other similar information. ${ }^{3}$ Through the personal contacts between Yugoslavia's Kosta P. Manojlović and prominent Bulgarian musician Dobri Hristov, the first attempts were made to institutionalize the musical and cultural connections between the First Belgrade Choral Society and the newly created Bulgarian Choral Union (1926), and later also with the South Slav Choral Union (Južnoslovenski pevački savez, SSCU), the largest musical organization in the Kingdom. As early as the first assembly of SSCU delegates (1924), it was confirmed that the organization worked on "integral South Slavic musical thought, which is only a precursor of the integral unity of the Slavic South," rejecting "every tribal and local background" and striving for the formation of "a unique South Slavic musical ideology [...] and unique South Slavic national consciousness!" 4

Apparently influenced by certain political and ideological aspects of the so-called integral Yugoslavism, the SSCU's program declaration initially included not only Serbs, Croats, Slovenes, but also Bulgarians. This way, it reflected Kosta Manojlovićs view of building a unified South Slavic musical and cultural concept, an idea, which he regarded as his mission and which he also promoted among Bulgarian figures of choral music. His call "We come to widely open the door to rapprochement among brotherly peoples, starting with a spiritual basis," published in the Slovo newspaper (1926), gave words to the intense drive for mutual cooperation, regardless of the obstacles and limitations posed by the political situation. ${ }^{5} \mathrm{As}$

\footnotetext{
2 Quoted in Zdravka Micheva, "Balgaro-yugoslavsko kulturno sblizhenie 1933-1940 [BulgarianYugoslav cultural rapprochement 1933-1940]," Istoricheski pregled 3 (1967): 4.

3 One example is the introductory article "Music Bulgaria and Yugoslavia" published in Muzikalen pregled 15-16 (1926): 1-2.

4 Quoted in Biljana Milanović, "The Contribution of Kosta P. Manojlović to the Foundation and Functioning of the Južnoslovenski pevački savez [South Slav Choral Union]," in Kosta P. Manojlović (1890-1949) and the Idea of Slavic and Balkan Cultural Unification, edited by Vesna Peno, Ivana Vesić, Aleksandar Vasić (Belgrade: Institute of Musicology SASA, 2017), 77.

5 Quoted in Dobri Hristov, Muzikalno-teoretichesko i publitsistichesko nasledstvo [Musical, theoretical and publicist heritage]. Volume 2, edited by Venelin Krastev (Sofia: Balgarska akademia na naukite, 1970), 218.
} 
a matter of fact, Manojlović was one of the few Yugoslav intellectuals at that time who publically expressed his view about the need for cultural collaboration with Bulgarians and actively made "efforts to put this strategy into practice." $6 \mathrm{He}$ found a fellow Pan-Slavist in Dobri Hristov, who wrote to him on the occasion of the First Yugoslav Musical Exhibition in Belgrade (1926): "We hope that the beginning of the spiritual community on the ground of the most supreme art-music, will echo deeply in the hearts of our political leaders, to welcome that beautiful day of the creation of a united and powerful Yugoslav state." 7 That is why it is not by chance that the First Belgrade Choral Society chose Dobri Hristov as its honorary member, recognizing not only his creative work, but also his support for the idea of South Slavic and Pan-Slavic cultural solidarity.

The chronology of these Bulgarian-Yugoslav musical contacts, of which there is information in the press and in the personal archives of Bulgarian musical figures, has yet to be thoroughly explored. They differed in intensity and were mainly realized through personal creative initiatives. Nevertheless, some documents show that from the middle of the 1920s the musical diplomacy anticipated, and in some cases was ahead of the process of thawing of political relations between the two neighboring countries. ${ }^{8}$ In fact, attempts at cooperation between the choral unions were often thwarted due to different circumstances resulting from the cold interstate relations. There were instances of this both on the Bulgarian and on the Yugoslav part. ${ }^{9}$ Hesitations of Bulgarian choral musicians as to joining Manojlovićs "grand idea" of a South Slavic cultural union were secretly reflected in the resolution of the Second Congress of the Bulgarian Choral Union (1928), where there were tactful hints to disputes between the choral centers in Belgrade and Zagreb. Regardless of this, the musical exchange did not stop, but there was an apparent differentiation in contacts, where connections between Bulgarian, Croatian and Slovenian musicians, societies and others were more active and predominated over those with the neighboring Serbian musical institutions. ${ }^{10}$

\footnotetext{
6 Ivana Vesić, Vesna Peno, "Kosta P. Manojlović: A Portrait of the Artist and Intellectual in Turbulent Times," in Kosta P. Manojlović (1890-1949) and the Idea of Slavic and Balkan Cultural Unification, edited by Vesna Peno, Ivana Vesić, Aleksandar Vasić (Belgrade: Institute of Musicology SASA, 2017), 13.

7 Dobri Hristov's letter to Kosta P. Manojlović, Sofia, April 3, 1926. Quoted in Milanović, “The Contribution of Kosta P. Manojlović," 78.

8 See Stefanka Georgieva, "The Idea of South Slavic Unity among Bulgarian Musicians and Intellectuals in the Interwar Period," in Kosta P. Manojlović (1890-1949) and the Idea of Slavic and Balkan Cultural Unification, edited by Vesna Peno, Ivana Vesić, Aleksandar Vasić (Belgrade: Institute of Musicology SASA, 2017), 42, 54-55.

9 Vesić, Peno, "Kosta P. Manojlović," 20.

10 Agapia Balareva. Horovoto delo v Bulgaria ot sredata na 19 vek do 1944 godina. (Prilozhenia. Chuzhdi horove v Bulgaria. Balgarski horove v chuzhbina) [Choral Work in Bulgaria from the
} 
Since the late 1920s and the early 1930s, the relations in politics and music have been dominated by the discussion about the "Macedonian folklore" - the most burning issue in Bulgarian-Serbian scientific arguments in the field of music. On the Bulgarian side, it had its own center, the Macedonian Scientific Institute (1923-1947, restored in 1990), which was created to study the history, ethnography, language and economic life of Macedonia, to gather materials about the national liberation struggle of Macedonian Bulgarians, and to introduce all of these to scientific and cultural circles in Bulgaria and abroad. It brought together scientists and public figures with Macedonian roots, and attracted foreign collaborators, specialists on the political and cultural aspects of the so-called Macedonian Question as regular and honorary members of the Institute. ${ }^{11}$ Among them was Ludvík Kuba (1863-1956), a Czech writer, artist and ethnologist, professor at the Academy of Fine Arts in Prague, who released an impressive collection of Slavic folk songs in his series Slovanstvo ve svých zpèvech (Slavs in Their Songs) (1884-1928). ${ }^{12}$

One of the books in his collection, featured 31 Macedonian folk songs from all regions of this South Slavic province divided among three countries after WWI. In the preface to this edition, he shared his views about the Bulgarian roots of Macedonian speech and the common metric and tonal characteristics of the folk melodies. This provoked a heated discussion between Bulgarian and Serbian scientists with strong political overtones. ${ }^{13}$ What stood out on the Bulgarian side was the position of Dobri Hristov, until then an unrivaled theoretician of our folk music, who laid the scholarly foundations for the studying of its rhythmic and metric features. ${ }^{14}$ However, he was not just an "office scientist," but also "a transcriber of tunes [...] who was always among the people at the time." ${ }^{15}$ Among

Middle of the $19^{\text {th }}$ Century to 1944. (Appendices. Foreign Choirs in Bulgaria. Bulgarian Choirs Abroad)] (Sofia: Balgarska akademia na naukite, 1992), 166, 213-216.

${ }^{11}$ Until WWII, the Institute had 110 scientists as members. Their studies were published in the Macedonian Review Magazine. See "Kratka istoria na Makedonskia nauchen Institut [A brief history of the Macedonian Scientific Institute]," accessed January 25, 2019, http://www.mni.bg/2013/06/ kratka-istoria-na-makedonskia-nauchen.html.

${ }^{12}$ Ludík Kuba, Slovanstvo ve svỳch zpevĕch. Sborník písni všech slovanskỳch nàrodů s pưvodními texty a českỳmi překlady. (Kniha XIV. Díl V. Písne juhoslovanské. Čast VIII. Písne Makedonské) [Slavs in Their Songs. A Collection of Songs of all Slavic Nations with Original Lyrics and Czech Translations (Book XIV, Part V Songs of Yugoslavia, Section VIII Macedonian songs] (Prague: self-published, 1928).

${ }^{13}$ See Vasil Stoin, "Nauka ili politika [Science or politics]," Muzikalen zhivot 6 (1928): 2-5.

14 These are the studies: "Ritmichnite osnovi na narodnata ni muzika [The rhythmic foundations of our folk music]," Sbornik s narodni umotvorenia 27 (1913): 1-48, and "Tehnicheskiyat stroezh na balgarskata narodna muzika (ritmika, metrika, tonalni i harmonichni osobenosti) [Technical structure of Bulgarian folk music (rhythmic, metric, harmonic and tonal characteristics)]," in Dobri Hristov, Muzikalno-teoretichesko, 63-125.

${ }^{15}$ Nikolay Kaufman, "Dobri Hristov - praktikat [Dobri Hristov-a man of practice]," in Dobri Hristov i balgarskiyat 20 vek, edited by Elena Toncheva (Sofia: Institut za izkustvoznanie, 2005), 63. 
the working materials preserved in his archive is his own collection of tunes from different areas and ethnic regions, including Bitola, Prilep, Štip, Kostur (Kastoria, now Greece), Struga, Galičnik and others. 16 These prove his continuous interest in "the Macedonian folk song, which is his great love." 17

In 1931, Hristov published a collection of 66 folk songs of Macedonian Bulgarians with an introductory study, where he formulated the main aim of the edition: to present in "a cultural and historical document the true national image of Macedonian Bulgarians through their tunes, exposed consciously or unconsciously to changes today, distancing them from their original kind." 18 The records of folk tunes included in the collection were provided as "proof outlining the general Bulgarian musical folk style, in which the songs of Macedonian Bulgarians are treated as its substantial part." ${ }^{19}$ In his comment, Hristov retained the objective scientific approach and did not allow himself to mention questions concerning the involvement of folklore with political and manipulative goals in the dispute between Bulgarian and Serbian ethnomusicologists. ${ }^{20}$ But the question remains how his position on "Macedonian folklore" affected his relations with his colleague Manojlović, for which only scarce documents are preserved in the archive of the Bulgarian musician.

In the beginning of the 1930s, Bulgaria's dialogue with its neighbors became more and more important to its foreign policy. However, the rapprochement with Yugoslavia turned out not to be so simple, because of a true Gordian knot of political, territorial, economic, ethnic, ecclesiastical and other controversial issues. Regardless of the attempts and efforts at reconciliation, the mutual distrust and the frequent provocations on the borders remained although the manifestations of the shared interest in improving the relations between the two countries were already a fact. A breakthrough came in 1933 when it "also became the policy of the governing circles in Yugoslavia and Bulgaria. [...] Belgrade's and Sofia's motives

\footnotetext{
16 Kristina Yapova, Arhivat na Dobri Hristov. Katalog. (Razdel II. 10. Rabotni materiali. II.10.1. Zapisi na muzikalen folklor) [Dobri Hristov's Archive. Catalogue. (Section II. 10. Working materials. II.10.1. Folk music recordings)] (Sofia: Matom, 2002), 73-79.

17 Kaufman, "Dobri Hristov - praktikat," 64.

${ }^{18}$ Lidia Litova-Nikolova, "Dobri Hristov i sbornikat mu '66 narodni pesni na makedonskite balgari [Dobri Hristov and his collection "66 Folk Songs of Macedonian Bulgarians"]," in Dobri Hristov $i$ balgarskiyat 20 vek, edited by Elena Toncheva (Sofia: Institut za izkustvoznanie, 2005), 73.

19 Ibid.

20 Dobri Hristov, "Makedonskite balgarski pesni [Macedonian Bulgarian songs]," in Dobri Hristov, Muzikalno-teoretichesko, 131-154. In the 1920s, this aspect was commented on by another Bulgarian ethnomusicologist, Vasil Stoin, in the abovementioned article "Nauka ili politika," 2-5. See also the opinion of Svetlana Zaharieva, "Muzikalno-folklorno izsledvane i nazionalisam. Pogled kam minaloto s missal za nastojashteto [Musical folklore research and nationalism. A look at the past with view for the present]," Bulgarian musicology 1 (1995): 19-38.
} 
were different, and so were their foreign policy directions and aims." ${ }^{21}$ Although covertly and mostly on the Yugoslav side, plans with a more distant prospect were considered: creating a country bordering two seas, the Adriatic and the Black Sea-a country that would unite all South Slavic peoples. ${ }^{22}$ Suggestions for the rapprochement process also came from great powers, which had their own plans, claims and spheres of influence on the Balkans.

Two significant meetings between Tsar Boris III of Bulgaria and King Alexander I of Yugoslavia in Belgrade and Varna in the autumn of 1933 opened the way for dialogue between the two countries. Both of them belonged to a new generation of politicians who witnessed and participated first-hand in the events on the fronts of the Balkan Wars and WWI. Their contacts, preceding the signing of the Balkan Pact, caused suspicion in the other Balkan neighbors (Romania, Greece, Turkey). ${ }^{23}$ In this unstable situation in international relations, Bulgaria changed governments with a shift in political orientation, but the course toward communication with Yugoslavia was supported. Of course, it had its opponents, particularly in the circles of the Internal Macedonian Revolutionary Organization (IMRO), whose armed actions frequently provoked tensions with the neighbors. In 1934, both countries went through turbulent events. For Bulgaria this was the May coup d'état, which established total control of Tsar Boris III over the country, and for Yugoslavia it was the assassination of King Alexander I in Marseille, which broadly echoed on the international scale.

However, the rapprochement process did not stop, and entered a new stage after 1935, one marked by the activity of two other political figures-Yugoslav Prime Minister Milan Stojadinović (1888-1961) and Georgi Kyoseivanov (1884-1960), a former Bulgarian Ambassador to Belgrade (1933-1934) and later on Prime Minister of Bulgaria. They made many skillful diplomatic moves and held numerous bilateral meetings with the allies from the Balkan Pact, maneuvering between the interests of the great powers, as well as isolating the internal opponents of rapprochement. This cause gave them the opportunity to gain popularity with a large part of their populations, which supported its successful realization. ${ }^{24}$ As a result of this, they achieved what was probably the most important: the arguments and mutual claims after WWI were left behind. ${ }^{25}$

Under these circumstances, another process developed as early as the beginning of the 1930s, where the participants were rarely in the focus of public attention.

\footnotetext{
${ }^{21}$ Manchev, Bistritsky, Bulgaria i neynite sasedi (1931-1939), 63, 67-68, 77.

22 Ibid., 69.

${ }^{23}$ Krastyo Manchev, Istoria na balkanskite narodi. Vol. 3 (1918-1945) (Sofia: Paradigma, 2008), 240-244.

${ }^{24}$ Manchev, Istoria na balkanskite narodi, 237-240.

${ }^{25}$ Manchev, Bistritsky, Bulgaria i neynite sasedi (1931-1939), 77.
} 
Based on an understanding that cultural exchange was necessary before the interstate relations can improve, a group of public figures from both countries "began to intensively promote the idea of creating an organization for cultural cooperation and rapprochement." ${ }^{26}$ For its realization, they had to overcome not only the opposition of the pro-German politicians, but also the skepticism and distrust of the part of intellectuals in both countries who were extremely nationalistically predisposed. The first steps were made alongside the establishment of the Yugoslav-Bulgarian Rapprochement Club (September 20, 1933) and the Yugoslav-Bulgarian League (September 24, 1933) in Belgrade, and the Bulgarian-Yugoslav Society (September $29,1933)$ in Sofia. Branches with cultural and student sections were opened in Zagreb, ${ }^{27}$ Ljubljana ${ }^{28}$ and in various Bulgarian cities. The organizations issued a one-time journal Bulgarian-Yugoslav Review (Sofia, 1934; Belgrade, 1935), ${ }^{29}$ and encouraged mutual visits of writers, actors, artists, opera singers and others. ${ }^{30}$ The guest performances of representative Bulgarian and Yugoslav groups became more frequent: the Gusla Choir, the Rodna pesen Choir, the Choir of the Sofia Faculty of Theology, the Obilić Academic Choral Society, the Stanković Choir (Belgrade), the Glasbena matica Choir (Ljubljana), the Cyril and Methodius Choir (Zagreb) and others, which maintained and enriched the tradition from the 1920s. ${ }^{31}$ Reports on their concerts commonly reflected on Slavic topics. ${ }^{32}$

In the time of the restless internal political situation in Bulgaria and Yugoslavia in 1934, the Bulgarian Ambassador in Belgrade was Dimo Kazasov (1886-1980), one of the most controversial figures in Bulgarian public life in the interwar years. He is said to have been a skillful demagogue whose biography is a true labyrinth of pragmatism and adaptation moves. A fierce opponent of the

\footnotetext{
${ }^{26}$ Micheva, "Balgaro-yugoslavsko kulturno sblizhenie," 8.

27 On the activities of the Bulgarian-Yugoslav League in Zagreb, see "Edma balgarska sedmiza v Zagreb [A Bulgarian week in Zagreb]," Slavjanski vesti 8 (1936): 5.

${ }^{28}$ See Afrodita Aleksieva et al. (Eds.), Balgaro-balkanski kulturni vzaimootnoshenia. 1878-1944 [Bulgarian-Balkan Cultural Relations 1878-1944] (Sofia: Bulgarian Academy of Sciences, 1986), 114.

${ }^{29}$ Micheva, "Balgaro-yugoslavsko kulturno sblizhenie," 14.

${ }^{30}$ Reviews of these guest performances from 1934 onward were regularly published in the Zlatorog magazine.

${ }^{31}$ Micheva, "Balgaro-yugoslavsko kulturno sblizhenie," 10-11, 19.

32 See Nikola Stanev, "Sblizhenie mezhdu Yugoslavia i Bulgaria [Rapprochement between Yugoslavia and Bulgaria]," Slavyanski glas 3-4 (1933): 7; "Yugoslavyano-balgarski klub [The Yugoslav-Bulgarian club]," Slavyanski glas 3-4 (1933) 106-108; "Koncerti. Gostovanje bugarskog hora studenata teološkog fakulteta iz Sofije u Jugoslaviji [Concerts. The guest performance of the Bulgarian choir of Faculty of Theology students from Sofia in Yugoslavia]," Cirilometodski vjesnik 3 (1934): 29-30; "Iz vjesti. Treći koncert Zagrebačke filharmonije [From the news. Third concert of the Zagreb Philharmonics]," Sv. Cecilija 1 (1935): 18; "Tarzhestvo na rodnata ni pesen. Hor 'Rodina' v Yugoslavia [A celebration of our native song. "Homeland" Choir in Yugoslavia]," Literaturen glas 269 (1935): 2.
} 
monarchy, Kazasov established and led his own political circle Zveno (1927-1934). ${ }^{33}$ But why did Tsar Boris III entrust him with the diplomatic position in Belgrade when he openly displayed hostility to the monarchical order? In one such situation - a demonstrative breach of protocol-his mission in Belgrade quickly came to an end. But other reasons prevailed for him to be appointed to this post. One of them was probably that Kazasov knew the internal issues of the neighboring country very well. Well-known was his activity to establish Bulgarian-Yugoslav cultural contacts, a cause to which he dedicated himself with a consistency unmatched by the twists in his political biography.

A more interesting fact is that Kazasov's political career went hand in hand with active literary and journalistic engagement. A large part of his texts was devoted to pressing social events, but Kazasov had a huge amount of written works, which includes about 30 books. One of them was Today's Yugoslavia (1938), published shortly after his brief diplomatic posting in Belgrade. The book was written "to familiarize the Bulgarian reader with the closest Balkan country in origin and fate-Yugoslavia. [...] to find out, based on facts, what blessed the grounds for cooperation, and what a great future of shared prosperity lies before the joint efforts of Bulgarians, Serbs, Croats and Slovenes, who share the same origin and soul." ${ }^{34}$ At the same time, Kazasov was the permanent chairman of the Union of Bulgarian-Yugoslav Societies from 1932 to 1941. His activity in this capacity was a clear illustration of the parallel processes of rapprochement in the spheres of political and cultural communication. The joint initiatives were reflected in the Bulgarian press in numerous articles, whose tone was predominantly positive and supportive. Here, we come to a curious fact. Even before the Treaty of Eternal Friendship was signed, the managers of the Belgrade and Sofia National Theaters exchanged suggestions on decorating the other country's actors with medals, which their monarchs approved. ${ }^{35}$

\footnotetext{
${ }^{33}$ Dimo Kazasov participated in three coups-in 1923, 1934 and 1944. After that he served as the Minister of Propaganda, Information and Arts (1944-1947), managing director of publishing houses, printing companies and in the printed production trade (1950-1953). See Ilcho Dimitrov, Minaloto, koeto beshe blizko, a stava vse po-dalechno. Sreshti i razgovori [The past, which was close, but is becoming more and more distant. Meetings and conversations] (Sofia: Universitetsko izdatelstvo "Sv. Kliment Ohridski," 1992); Borislav Gardev, "Dimo Kazasov - talantliviyat demagog [Dimo Kazasov—the talented demagogue]," accessed February 4, 2019, https://liternet.bg/publish4/ bgyrdev/podir/01_12.htm.

${ }^{34}$ Dimo Kazasov, Dneshna Yugoslavia [Today's Yugoslavia] (Sofia: without publishing details, 1938), 3. He wrote only short notes about his diplomatic mission in Yugoslavia, spread throughout his numerous publications. See Dimo Kazasov, "Iskri ot burni godini [Fragments from lively years]," in Izbrani proizvedenia. With a foreword by the author, editor and compiler Stefan Zhelev (Sofia: Otechestven front, 1987), 419-420.

${ }^{35}$ Aleksieva et al. (Eds.), Balgaro-balkanski kulturni vzaimootnoshenia, 172.
} 
There were not any musicians among the founders of the Union of Bulgarian-Yugoslav Societies. ${ }^{36}$ The names of music critic Ivan Kamburov, Dimitar Hadzhigeorgiev, president of the Academy of Music, and Andrey Stoyanov, piano teacher and a member of the Bulgarian Academy of Sciences, were mentioned in a letter from 1935, which the editorial board of the World Encyclopedia in Belgrade sent them with an invitation to participate as collaborators in the publication. ${ }^{37}$ The press published messages about the connections of Bulgarian scientists with the Institute of Balkan Studies established in Belgrade (1934), as well as information about their publications included in the magazine La revue internationale des Etudes balkaniques and the series Knjiga o Balkanu (A Book About the Balkans). ${ }^{38}$ This way, along with the foundation of the Bulgarian-Yugoslav societies, bilateral contacts also became more active on the level of high science. The business correspondence between the managers of the Sofia National Opera and the Belgrade National Theater reveals another perspective of the cultural relations, related to guest performances of opera singers, negotiating new theater performances and other aspects. ${ }^{39}$ These specific areas of bilateral cooperation are yet to be more thoroughly researched.

The musical exchanges in the 1930s included a new generation of Bulgarian musicians-instrumentalists and conductors, singers of the Sofia opera, symphony orchestras, chamber music ensembles and others. In 1933, composers founded the Contemporary Music Society, which also actively assisted in the emergence of new forms and content in the contacts with the Yugoslav musical culture. The series of visits of representative Bulgarian musical groups opened with a concert by the Sofia Academy Symphony Orchestra in Belgrade in May 1934. The conductor was Sasha Popov (1899-1976), a virtuoso violinist with a brilliant international career, who entered this line of work to establish himself as a founder of symphonic performing arts in Bulgaria. ${ }^{40}$

These Bulgarian visits preceded the emergence of another course in the musical exchange between the two neighboring countries, which developed in the next stage, the period 1937-1940, and exceeded its borders, marking a culmination of cultural contacts of its kind, not only in the decade in question but the entire previous century. It is undoubtedly a reflection of the favorable development in bilateral relations following the Treaty of Eternal Friendship, which the two prime ministers, Georgi Kyoseivanov and Milan Stojadinović, signed in Belgrade on January 24, 1937. In its essence, the agreement turned out to be a concise declaration, with no

\footnotetext{
${ }^{36}$ See Annual report of the Bulgarian-Yugoslav Society 1933-1934. Without publishing details; Annual report of the Bulgarian-Yugoslav Society 1934-1935. Without publishing details.

${ }^{37}$ Aleksieva et al. (Eds.), Balgaro-balkanski kulturni vzaimootnoshenia, 55-57.

38 Ibid., 59, 64, and others; Micheva, "Balgaro-yugoslavsko kulturno sblizhenie," 15-16.

${ }^{39}$ Aleksieva et al. (Eds.), Balgaro-balkanski kulturni vzaimootnoshenia, 146-147, 155, 166.

40 The program was not announced in the press. The same year, Sasha Popov founded the Tsar's Military Symphony Orchestra, a predecessor of the Sofia Philharmonics, which he led from 1947 to 1956.
} 
other provisions or appendices to specify the mutual obligations and rights of the parties. ${ }^{41}$ It did not give answers to the most important questions in connection to the relations between Bulgaria and Yugoslavia: what their aims were, what they had in common, and what their national interests were. ${ }^{42}$ Guessing on all of these raised suspicion in the allies, but especially in the neighboring countries. The distrust toward the Bulgarian-Yugoslav "eternal friendship" grew, accelerated also by the political situation, which became more and more complicated, with the looming outbreak of a new military conflict on the European continent. According to Krastyo Manchev, one of the authoritative researchers of this historical event, "the treaty was not just a platonic outpouring of friendly sentiments." ${ }^{43}$ In fact, not only him, but also other Bulgarian historians assumed that there was a secret agreement behind it, based around the desire of both countries to have direct access to the Aegean Sea. However, these guesses have not been confirmed yet by documents from diplomatic archives. ${ }^{44}$ For Bulgaria, the Treaty was an important act, realizing its desire for neighborliness with the Kingdom of Yugoslavia, and a step toward the overcoming its international isolation after WWI.

As a matter of fact, there is only one area where the assessments of historians are amazingly unanimous-cultural cooperation between the two countries. Even if we presume that the political propaganda around the agreement had its impact on some of the publications in the Bulgarian and Yugoslav press, the media defining it as "a blessed deed" and "a reliable tool of peace" prevailed. ${ }^{45}$ Famous Bulgarian and Yugoslav artists, writers, actors and musicians joined the cultural events, and their presence was not merely an expression of formal support for the consensus achieved between the states, but participation in making the cultural dialogue with long historical traditions more active. 46

The effects of the Treaty on the musical exchange appeared right after its signing, with a series of symphony and chamber music concerts (Belgrade and

\footnotetext{
${ }^{41}$ Krastyo Manchev, Yugoslavia i mezhdunarodnite otnoshenia na Balkanite 1933-1939 (Sofia: Balgarska akademia na naukite, 1989), 152-165.

42 Manchev, Istoria na balkanskite narodi, 262-272; See also Manchev, Bistritski, Bulgaria i neynite sasedi (1931-1939), 226-227.

${ }^{43}$ Manchev, Istoria na balkanskite narodi, 268.

${ }^{44}$ There were hints about this also by the Yugoslav allies in the Balkan Pact. See Aleksieva et al. (Eds.), Balgaro-balkanski kulturni vzaimootnoshenia, 232-234.

${ }^{45}$ St.[?] Koledarov, "Edno blagosloveno delo [A blessed deed]," Slavjanska beseda 2 (1937): 76-77; "Dogovor za prijatelsto mezdu Balgaria i Yugoslavija [Treaty of friendship between Bulgaria and Yugoslavia]," Slavjanski vesti 1 (1937): 1-2; Nikola Stanev, "Kakvo predstavljavat sdruzenite Balgaria i Yugoslavija [What are the allied Bulgaria and Yugoslavia like]," Slavjanski vesti 12 (1937): 3-4; "Edin siguren instrument na mira. Balgaro-yugoslavskijat dogovor za vechna druzba [A reliable tool of peace. The Bulgarian-Yugoslav treaty of eternal friendship]," Chas 33 (April 19, 1937): 4. On the reviews in the Belgrade newspapers Politika and Pravda, see Micheva, "Balgaro-yugoslavsko kulturno sblizhenie," 24-25.

${ }^{46}$ Micheva, "Balgaro-yugoslavsko kulturno sblizhenie," 23-28.
} 
Sofia, March-April 1937) and multiple guest performances of musicians-singers and instrumentalists - which exceeded in scale the agreement's political aspects. ${ }^{47}$ On March 7, 1937, a concert was performed at the National Theater, "dedicated to Yugoslav music on the occasion of the constitutive congress of the BulgarianYugoslav societies in Bulgaria." The central figures who contributed to its realization were Dimo Kazasov, who gave a talk on "The rapprochement between Bulgarian and Yugoslav peoples," and music critic Ivan Kamburov, who presented, in his own words, "contemporary Yugoslav music, with a special focus" on composers of the "Belgrade group." Nevertheless, the program was thematically heterogeneous. It featured mainly solo and choral works by Davorin Jenko, Stanislav Binički, Jakov Gotovac and Miloje Milojević, but "Pesen" from Petar Konjović's opera Koštana and a String Quartet by Josip Slavenski were also performed. Soloists of the Sofia National Opera, the Kaval Choir and the Avramov Quartet participated. Reports from the event emphasized the presence of a "sophisticated audience"-intellectuals, writers and notable figures. ${ }^{48}$ Letters addressed to the prime ministers of Bulgaria and Yugoslavia were read, and they were proclaimed honorary members of the Slavjanska beseda Society. ${ }^{49}$

Another response to the political "fraternization" was a symphonic concert dedicated to Bulgarian music, which the Belgrade Philharmonics gave one month later (April 3, 1937) in the Grand Hall of the Kolarac People's University ${ }^{50}$ and was conducted by Tsanko Tsankov, a composer and professor at the National Academy of Music in Sofia. The program specified that the concert took place "under the auspices of the Yugoslav Prime Minister Milan Stojadinović." In the course of time, however, the political context of this event "has been forgotten," and it remained in the annals of Bulgarian musical history as the first joint participation of composers from the Contemporary Music Society abroad. ${ }^{51}$ The works of Petko Staynov (concert overture Balkan), Veselin Stoyanov (Capriccio), Ljubomir Pipkov (interludes from the opera Yaninite devet bratya [Yana's Nine Brothers]), Dimitar Nenov (Symphonic Sketches), Tsanko Tsankov (songs for soprano and orchestra)

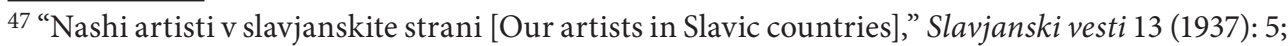
"Belgradski operni artisti na poseshtenije v nashata opera [Belgrade opera artists visit our opera]," Muzikalna misal 2 (1937): 12-13.

48 "Konzerti. Yugoslavjanski: Savmesten konzert s Balgaro-Yugoslavskoto druzestvo [Concerts. Yugoslav joint concert with the Bulgarian-Yugoslav society]," Slavjanska beseda 2 (1937): 89; Ivan Kamburov, "Konzert z yugoslavska muzika [Concert of Yugoslav Music]," Slavjanska beseda 2 (1937): 93-94.

49 "Iz zhivota na Slavjanska beseda [From the life of the Slavic talk]," Slavjanska beseda 2 (1937): 189-191.

50 "Iz slavjanskite strani. Belgrad. Sinfonichen konzert na Belgradskata filharmonija, posveten na Balgarskata muzika [From Slavic countries. Belgrade. Belgrade Philharmonics' symphonic concert dedicated to Bulgarian music]," Slavjanski vesti 14 (1937): 4-5.

${ }^{51}$ Ivan Hlebarov, Novata balgarska muzikalna kultura (izsledvane v dva toma). Tom parvi: 1878-1944 [The New Bulgarian Musical Culture (study in two volumes). Volume 1: 1878-1944] (Sofia: Haini, 2003), 299-300.
} 
and Pancho Vladigerov (concert overture Zemya [Earth]) included in the program were an original review of their creative achievements in the mid-1930s.

On the Bulgarian side, support for the Treaty of Eternal Friendship was also demonstrated with a Concert of Yugoslav Music by the State Philharmonics in the hall of the National Theater in Sofia on April 12, 1937, held under the auspices of the Minister of Public Enlightenment, Nikolay Nikolaev, and with Mirko Polić as guest conductor. The program featured works by Petar Konjović, Matija Bravničar, Mirko Polić, Miloje Milojević, Krešimir Baranović, Josip Slavenski and Milenko Živković, who were present at the concert, according to the press. Composer Veselin Stoyanov, a member of the Contemporary Music Society, delivered an address "about the musical collaboration between the two countries." 52 This way, regardless of the political patronage for the event, it became an occasion for new prospects of professional networking with the Yugoslav musicians. Such an emphasis on bilateral musical and cultural relations can also be found in the extensive review of the concert, where we can read: "for the art of music, there are no political boundaries. [...] Sooner or later, the compositions with artistic merits leap across wire fences and all kinds of artificial obstacles." ${ }^{53}$

The speed with which musical exchange surpassed the framework of political patronage was discussed by many people and collective art initiatives. During the period 1935-1939, for example, the cultural events of the Balgarsko rodno izkustvo (Bulgarian Native Art) society included more than 80 concert programs, with evenings dedicated to Hungarian, French, Czechoslovak, German, Italian, Polish, Romanian, Russian, Greek and Turkish music. ${ }^{54}$ It is easy to notice from this set of the national musical cultures that the organizers did not care much about the political situation or participation restrictions on musicians from countries that were members of one political alliance or another. The concerts included two Evenings of Yugoslav Music, featuring one of the most impressive ensembles of the Kingdom. At the first concert, the Belgrade Philharmonic Orchestra (conductor Lovro Matačić) performed works by Krešimir Baranović (overture to the opera Striženo-košeno [Sheared-Mowed]), Lucijan M. Škerjanc (Suite for string quartet), Božidar Kunc (Concerto for Piano and Orchestra in B Minor, op. 22, the soloist was not specified), Petar Konjović (prelude to the opera Koštana), Jakov Gotovac (Orači [The Ploughmen] and Symphonic kolo), Vojislav Vučković (Symphony) and Svetomir Nastasijević (Symphonic Suite). The

\footnotetext{
52 "Iz slavjanskite strani. Sofia. Sinfonichen konzert na Darzavnata filharmonija s yugoslavska muzika [From Slavic countries. Sofia. Symphonic concert of the State Philharmonics with Yugoslav music]," Slavjanski vesti 14 (1937): 5.

53 Vasil Spasov, "Yugoslavskijat simfonichen konzert [Yugoslav symphonic concert]," Chas 32 (April 19, 1937): 1.

54 Sofia Vasileva, "Kulturno druzestvo 'Balgarsko rodno izkustvo' 1929-1939 [The 'Bulgarian Native Art' culture society, 1929-1939]," Izdatel 1-2 (2006): 22-24.
} 
second one presented diverse genres and consisted of three parts: Part I featured Petar Kristićs Scherzo, Josip Štolcer-Slavenski's Nokturno and Petar Stojanović's symphonic poem Sava; in Part II the Zagreb String Quartet performed works by Ivan Mane Jarnović, Krsto Odak and Petar Konjović; and Part III were the Zagreb String Quartet and performances of singers. ${ }^{55}$

At the same time, messages appeared in the press about forthcoming guest performances of the opera ensembles from Belgrade and Zagreb in Sofia upon the invitation of the Native Art Society, which, however, were not confirmed by further information. Probably, they announced already the initiatives included in the cultural program, which in some cases remained unrealized or were carried out later and with the support of other musical institutions. One such event was the visit of the ballet ensemble of the Belgrade National Theater in June 1938. There was information about its preparation in the correspondence between the managers of the national theaters in Sofia and Belgrade. ${ }^{56}$ The ensemble performed a rich program, which included the ballets Đavo u selu (The Devil in the Village) by Fran Lhotka and The Firebird by Igor Stravinsky, as well as parts from Pyotr I. Tchaikovsky's Symphony No. 5. The artistic mastery of the Yugoslav dancers and "the strongly expressive choreography, rich in rhythm and forms," were highly appreciated by Bulgarian critics. ${ }^{57}$

But one of the peak of the Bulgarian-Yugoslav musical collaboration in the 1930s was still to come. In December 1939, Vladimir Tenev, the manager of the National Theater in Sofia, and the representative of the Zagreb-based UJDA association in Bulgaria signed a contract to stage Jakov Gotovac's opera Ero s onoga svijeta (Ero the Joker) in Sofia. ${ }^{58}$ The production was made entirely by Bulgarian artistic staff, consisting of young performers like conductor Asen Naidenov, director Dragan Kardzhiev, singers Georgi Belev, Pavel Elmazov, Mihail Lyutskanov, Nina Karova and others, who had already proved their creative abilities. ${ }^{99}$ It is a curious fact that Bulgarian tenor Stoyan Kolarov appeared as a guest performer in one of the central roles, Mića. At that time, he was a permanent member of the Zagreb opera, and was widely recognized by critics as one of its best interpretive singers. ${ }^{60}$ Moreover, the choreographer was Nina Kirsanova, the head of the ballet ensemble

55 "Iz glazbenog svijeta. Veliki uspjeh hrvatskih kompozitora i muzičara na festival u Bugarskoj [From the world of music. Great success of Croatian composers and musicians at a festival in Bulgaria]," Ćirilometodski vjesnik 10 (1937): 98-99.

56 Aleksieva et al. (Eds.), Balgaro-balkanski kulturni vzaimootnoshenia, 183-184.

${ }^{57}$ Maria Danailova, "Belgradskijat balet v Balgaria [The Belgrade ballet in Bulgaria]," Zlatorog XIX (1938): 275-278.

58 Aleksieva et al. (Eds.), Balgaro-balkanski kulturni vzaimootnoshenia, 188-189.

59 Zlata Bozhkova, Sofijska narodna opera. Memoari [Sofia National Opera. Memoirs] (Sofia: Nauka i izkustvo, 1975), 163.

60 Petar Mavrov, Tenorat Stojan Kolarov [The Tenor Stoyan Kolarov] (Varna: Morski svjat, 2019), 23-35. 
of the Belgrade National Theater. ${ }^{61}$ The premiere, which took place on February 28, 1940 , was attended by the composer, Jakov Gotovac. An extensive interview was made on the occasion of his visit to Bulgaria, in which he expressed his satisfaction with the performance and the opportunity to establish personal contacts with Bulgarian musicians and composers. ${ }^{62}$

The initial arrangements for the production were made in the conditions where a military conflict had already erupted, beginning with the "strange war" of Germany and the USSR against Poland (September 1-17, 1939). The old continent became the stage of another "theatrical" spectacle, which soon outgrew its territory and turned into a new World War. It did not miss the Balkans. The attack of Hitler's Germany on Yugoslavia and Greece (April 6, 1940) and the strong pressure on Bulgaria and Yugoslavia to join the Tripartite Pact revived the tension in their interstate relations. No less complicated were the internal political problems of both countries. In Yugoslavia, they spiraled into a political crisis so big that "the previously signed alliances began to be doubted, along with the previously pursued foreign policy and sometimes the integrity and the borders of the country." ${ }^{63}$ In Bulgaria, Georgi Kyoseivanov's government was replaced by the cabinet of Bogdan Filov (April 15, 1940), formed with a team of Germanophiles. The adopted policy of rapprochement with Yugoslavia was abandoned, and a clear disrespect for the Treaty of Eternal Friendship was shown. Differences emerged in the Union of Bulgarian-Yugoslav Societies regarding its character and courses of action. Growing increasingly complicated, the political situation impacted the intensity of the cultural connections, even leading them to break, according to some researchers. ${ }^{64}$

But was this really the case? When it comes to Bulgarian-Yugoslav musical connections during those years, we can find exceptions that show how conditional the attempts are to typologize the relations of music and politics in different stages or periods. An example of this can be seen in the life and creative work of Bulgarian composer Pancho Vladigerov (1899-1978), who left Germany in 1932 and returned

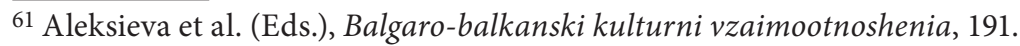

62 This interview, along with Gotovac's correspondence with Bulgarian musicians, was published in the study Rozalina Spasova, Stefanka Georgieva, "Unknown Letters of Jakov Gotovac, Boris Papandopulo, Josip Štolcer Slavenski in Boris Gaidarov's Archives (From the History of BulgarianCroatian Music Contacts between the 1920s and the 1940s)," Arti Musices 42/1 (2011): 25-30. A review by P. Rudevitz (alias of Vladimir Vassilev), published in the Zlatorog magazine in 1940 defines Gotovac's opera as "an example of folk art on national motives." Quoted in Borjana Mangova, "Deynostta na Sofiyskata narodna opera kato obekt na otrazhenie v spisanie Zlatorog (1920-1943) [The activity of the Sofia People's Opera as a subject of reflection in the Zlatorog magazine (19201943)]," in VII Akademichni proletni chetenia 'Balgarskata muzikalna kultura prez 20-te i 30-te godini na 20 vek,' edited by Anda Palieva (Sofia: Nazionalna muzikalna akademia, 2017), 268-281.

${ }^{63}$ Manchev, Istoria na balkanskite narodi, 306.

${ }^{64}$ Micheva, "Balgaro-yugoslavsko kulturno sblizhenie," 29.
} 
to Bulgaria for good. ${ }^{65} \mathrm{He}$ did not stop performing as a guest in the big musical centers, but the performances were clearly concentrated in central Europe and the Balkan countries (Warsaw, Budapest, Bucharest), and particularly in the neighboring Yugoslavia. Vladigerov gave multiple chamber music concerts and concerts of his own music in Belgrade (January 1935, February 1937) and Zagreb (1937, 1938, 1939), and in Ljubljana his opera Tsar Kaloyan was staged (May 1937). At the concerts, the audience did not spare its "spontaneous and sincere applauses, giving him recognition not only as a renowned world artist, but also as one of the greatest and most talented representatives of South Slavic music." 66

During those years, Vladigerov created a series of major instrumental and orchestral works, including his Symphony No. 1 (op. 33, 1939). Its first performance had a fate worth noting. ${ }^{67}$ After the Sofia Tsar's Military Symphony Orchestra formally refused to perform it without providing a reason, it was played for the first time by the Radio Belgrade Symphony Orchestra under the baton of Mihailo Vukdragović (1940). The latter wrote a review of Vladigerov's piece, emphasizing his contribution to contemporary Bulgarian musical culture. ${ }^{68}$ This concert turned into a sensation in the Sofia press, which the newspaper Dnevnik ran on the front page under the headline "Big production of Pancho Vladigerov rejected in Bulgaria reaps brilliant success in Belgrade." ${ }^{69}$ The article included fragments of an interview with the composer, in which he praised "the great musical culture of the splendid orchestra of Radio Belgrade," but also expressed his sincere regrets that his latest work was not performed for the first time in his native country. ${ }^{70}$ As a matter of fact, the program of this concert in Belgrade included another Bulgarian first performance-Symphony No. 1 (in F Major) by Boyan Ikonomov (1900-1973), a composer from the same generation as Vladigerov, whose work was written in Paris in 1937. It is strange that it remained outside the scope of attention of Bulgarian and Yugoslav musical critique. ${ }^{71}$

65 The motives for this were discussed by his biographer, and were mainly personal, not related to the complicated political situation in Germany. See Evgeni Pavlov-Klosterman, Pancho Vladigerov (Sofia: Muzika, 2000), 153.

${ }^{66}$ Novosti (January 25, 1935). Quoted in Pavlov-Klosterman, Pancho Vladigerov 133.

67 Pavlov-Klosterman, Pancho Vladigerov, 145.

68 Vreme (April 4, 1940). Quoted in Pavlov-Klosterman, Pancho Vladigerov, 145.

${ }^{69}$ P.Petko Tiholov, "Edna goljama produkzija na Pancho Vladigerov, othvarlena ot Balgaria, pozana bljaskav uspeh v Belgrad [Big production of Pancho Vladigerov rejected in Bulgaria reaps brilliant success in Belgrade]," Dnevnik (April 28, 1940): 1.

70 After Belgrade, Vladigerov's Symphony No. 1 was performed in Bucharest (April 12, 1940), and its first performance in Sofia was not until 1945. See Pavlov-Klosterman, Pancho Vladigerov, 144.

${ }^{71}$ Boyan Ikonomov studied composition and conducting under Vincent d'Indy at the Schola Cantorum in Paris. In 1934, he specialized in conducting with Felix Weingartner in Switzerland. From the 1930s to the 1960s, he worked at the musical department of the Sofia radio. His early works 
Vladigerov's creative activity continued in the beginning of the new decade. In 1940, he visited Zagreb, wrote his String Quartet No. 1 and dedicated it "to Prof. Milan Graf and his Zagreb Quartet." After that, his works were performed at the Bulgarian Music Week in Ljubljana (1940). These performances of Vladigerov's music in the Yugoslav musical centers require more detailed research and exploration of new historiographical materials. Because they are among the strongest proofs of the continuity of the musical contacts and their independence from the political situation and circumstances.

The 1930s mark the golden pages in the history of Bulgarian-Yugoslav musical relations, which remained unparalleled for the rest of the $20^{\text {th }}$ century. Belonging into the complex mix of geopolitical and Balkan dependencies, as well as in the focus of the complicated neighborly relations after WWI, they reflect certain specific connections between politics and music, mapping the "internal" stages in their development. The first period, from 1926(28) to 1931, is when culture was ahead of the thawing of political dialogue with initiatives for creative rapprochement (the First Belgrade Choral Society and the Bulgarian Choral Union). During the second one (1931-1937), which followed the process of political rapprochement, the cultural contacts are institutionalized with the activity of the Bulgarian-Yugoslav leagues in Belgrade and Sofia and other organizations, through joint initiatives in the fields of science, literature and arts. The third stage (1937-1940) marks the culmination in the musical and cultural exchange between the two countries, which builds up through the professional contacts of a new generation of Bulgarian and Yugoslav composers, with the participation of musical institutions, orchestras, operas and other actors. But the events on the political scene are just markers which delineate the chronology of the cultural rapprochement process up to the signing of the Treaty of Inviolable Peace and Eternal Friendship. In this sense, they assist the charting of different fields of the musical exchange, in which cooperation surpasses the ideological framework of the political situation and achieves relative independence. The leading role in reaching this level was played by prominent Bulgarian and Yugoslav intellectuals, whose empathy and participation in the intercultural dialogue remain a topic for future research. ${ }^{72}$

consist predominantly of chamber music and instrumental genres. His first symphonic work, as well as a large part of his works remain unfamiliar to this day and have not been published in Bulgaria.

72 This chapter was translated from Bulgarian to English by Mariana Pavlova. 


\section{Primary sources:}

Chas [Чac], Sofia, 1935-1940

Ćirilometodski vjesnik, Zagreb, (1933-1940)

Dnevnik [Дневник], Sofia, 1902-1944

Literaturen glas [Литературен глас], Sofia, 1928-1944

Muzikalen pregled [Музикален преглед], Stara Zagora, 1924-1929

Muzikalen zhivot [Музикален живот], Sofia, 1928-1931
Muzikalna missal [Музикална мисъл], София, 1936-1939

Slavjanska beseda [Славянска беседа], Sofia, 1937-1943

Slavyanski glas [Славянски глас], Sofia, 1902-1940

Slavjanski vesti [Славянски вести], Sofia, 1937-1943

Sv. Cecilija, Zagreb, 1887-

Zlatorog [Златорог], Sofia, 1920-1943

\section{Internet sources:}

Gardev, Borislav. Dimo Kazasov - talantliviyat demagog, accessed on February 4, 2019, https://liternet.bg/publish4/bgyrdev/podir/01_12.htm.

"Kratka istoria na Makedonskia nauchen institute." accessed on January 25, 2019, http:// www.mni.bg/2013/06/kratka-istoria-na-makedonskia-nauchen.html.

\section{References:}

Balareva, Agapia. [Баларева, Агапия] Horovoto delo v Bulgaria ot sredata na 19 vek do 1944 godina. Sofia: Balgarska akademia na naukite,1992. [Orig. in Bulgarian Cyrillic]

Balgaro-balkanski kulturni vzaimootnoshenia, 1878-1944, edited by Afrodita Aleksieva, Lilia Kirova, Nikolay Savov, Ginka Stamenova, Antoaneta Todorova. Sofia: Balgarska akademia na naukite, 1986. [Orig. in Bulgarian Cyrillic]

Bozhkova, Zlata. [Божкова, Злата] Sofijska narodna opera. Memoari. Sofia: Nauka i izkustvo, 1975. [Orig. in Bulgarian Cyrillic]

Dimitrov, Ilcho. [Димитров, Илчо] Minaloto, koeto beshe blizko, a stava vse po-dalechno. Sreshti i razgovori. Sofia: Universitetsko izdatelstvo "Sv. Kliment Ohridski," 1992. [Orig. in Bulgarian Cyrillic]
Georgieva, Stefanka. "The Idea of South Slavic Unity among Bulgarian Musicians and Intellectuals in the Interwar Period." In Kosta P. Manojlović (1890-1949) and the Idea of Slavic and Balkan Cultural Unification, edited by Vesna Peno, Ivana Vesić, Aleksandar Vasić, 37-56. Belgrade: Institute of Musicology SASA, 2017.

Hlebarov, Ivan. [Хлебаров, Иван] Novata balgarska muzikalna kultura (izsledvane $v$ dva toma). Tom parvi: 1878-1944. Sofia: Haini, 2003. [Orig. in Bulgarian Cyrillic]

Hristov, Dobri. [Христов, Добри] Muzikalno-teoretichesko i publitsistichesko nasledstvo. Vol. 2, edited by Venelin Krastev. Sofia: Balgarska akademia na naukite, 1970. [Orig. in Bulgarian Cyrillic] 
Hristov, Dobri, "Ritmichnite osnovi na narodnata ni muzika." Sbornik s narodni umotvorenia 27 (1913): 1-48. [Orig. in Bulgarian Cyrillic]

Hristov, Dobri, “Tehnicheskijat strojez na balgarskata narodna muzika (pitmika, metrika, tonalni i harmonichni osobenosti)." In Dobri Hristov. Muzikalno-teoretichesko i publizistichno nasledstvo. Vol. 2, edited by Venelin Krastev, 63-127. Sofia: Balgarska academia na naukite, 1970. [Orig. in Bulgarian Cyrillic]

Hristov, Dobri. "Makedonskite balgarski pesni." In Dobri Hristov. Muzikalno-teoretichesko i publizistichno nasledstvo. Vol. 2, edited by Venelin Krastev, 131-154. Sofia: Balgarska academia na naukite, 1970. [Orig. in Bulgarian Cyrillic]

Kaufman, Nikolay. [Кауфман, Николай] "Dobri Hristov - praktikat." In Dobri Hristov i balgarskiyat 20 vek, edited by Elena Toncheva, 62-67. Sofia: Institut za izkustvoznanie, 2005. [Orig. in Bulgarian Cyrillic]

Kazasov, Dimo. [Казасов, Димо] Dneshna Yugoslavia. Sofia, 1938. [Orig. in Bulgarian Cyrillic]

Kazasov, Dimo. Izbrani proizvedenia. [With a foreword by the author] Editor and compiler Stefan Zhelev. Sofia: Otechestven front, 1987. [Orig. in Bulgarian Cyrillic]

Kuba, Ludvík. Slovanstvo ve svỳch zpevĕch. Sborníkpísni všech slovanskỳch nàrodì spưvodními texty a českỳmi překlady. (Kniha XIV. Díl V. Písne juhoslovanské. Čast VIII. Písne Makedonské). Prague: self-published, 1928.

Litova-Nikolova, Lidia. [Литова-Николова, Лидия] “Dobri Hristov i sbornikat mu '66 narodni pesni na makedonskite balgari”' In Dobri Hristov $i$ balgarskiyat 20 vek, edited by Elena Toncheva, 72-77. Sofia: Institut za izkustvoznanie, 2005. [Orig. in Bulgarian Cyrillic]
Manchev, Krastyo, Bistritski, Valerian. [Манчев, Крьстьо, Бистрицки, Валериан] Bulgaria $i$ neynite sasedi (1931-1939). Politicheski i diplomaticheski otnoshenia. Sofia: Nauka i izkustvo, 1978. [Orig. in Bulgarian Cyrillic]

Manchev, Krastyo. Istoria na balkanskite narodi. Tom 3, (1918-1945). Sofia: Paradigma, 2008. [Orig. in Bulgarian Cyrillic]

Manchev, Krastyo. Yugoslavia i mezhdunarodnite otnoshenia na Balkanite 1933-1939. Sofia: Balgarska academia na naukite, 1989. [Orig. in Bulgarian Cyrillic]

Mangova, Borjana. [Мангова, Боряна] "Deynostta na Sofiyskata narodnata opera kato obekt na otrazhenie v spisanie Zlatorog (1920-1943)." In VII Akademichni proletni chetenia 'Balgarskata muzikalna kultura prez 20-te i 30-te godini na 20 vek, edited by Anda Palieva, 268-281. Sofia: Nazionalna muzikalna akademia, 2017. [Orig. in Bulgarian Cyrillic]

Mavrov, Petar. [Мавров, Петър] Tenorat Stojan Kolarov (1907-1964). Varna: Morski svjat, 2019. [Orig. in Bulgarian Cyrillic]

Micheva, Zdravka. [Мичева, Здравка] "Balgaro-yugoslavsko kulturno sblizhenie 1933-1940." Istoricheski pregled 3 (1967): 3-29. [Orig. in Bulgarian Cyrillic]

Milanović, Biljana. “The Contribution of Kosta P. Manojlović to the Foundation and Functioning of the Južnoslovenski pevački savez [South-Slav Choral Union]." In Kosta P. Manojlović (1890-1949) and the Idea of Slavic and Balkan Cultural Unification, edited by Vesna Peno, Ivana Vesić, Aleksandar Vasić, 65-90. Belgrade: Institute of Musicology SASA, 2017.

Otchet na Balgaro-yugoslavskoto druzhestvo za godinata 1933-1934. [Without publishing details]. [Orig. in Bulgarian Cyrillic] 
Otchet na Balgaro-yugoslavskoto druzhestvo za godinata 1934-1935. [Without publishing details]. [Orig. in Bulgarian Cyrillic] Pavlov-Klosterman, Evgeni. [Павлов-Клостерман, Евгени] Pancho Vladigerov. Sofia: Muzika, 2000. [Orig. in Bulgarian Cyrillic]

Spasova, Rozalina, Georgieva, Stefanka. "Unknown letters of Jakov Gotovac, Boris Papandopulo, Josip Štolzer Slavenski in Boris Gaidarov's Archives (From the History of Bulgarian-Croatian Music Contacts between the 1920s and the 1940s)." Arti Musices 1 (2011): 5-35.

Tiholov, Petko. [Тихолов, Петко] Kam varhovete na izkustvoto. Sofia: Muzika, 1979. [Orig. in Bulgarian Cyrillic]
Vesić, Ivana, Peno, Vesna. "Kosta P. Manojlović: A Portrait of the Artist and Intellectual in Turbulent Times." In Kosta P. Manojlović (1890-1949) and the Idea of Slavic and Balkan Cultural Unification, edited by Vesna Peno, Ivana Vesić, Aleksandar Vasić, 13-25. Belgrade: Institute of Musicology SASA, 2017.

Yapova, Kristina. [Япова, Кристина] Arhivat na Dobri Hristov. Katalog. Sofia: Matom, 2002. [Orig. in Bulgarian Cyrillic] Zaharieva, Svetlana. [Захариева, Светлана] "Muzikalno-folklorno izsledvane i nazionalisam. Pogled kam minaloto s missal za nastojashteto." Bulgarian musicology 1 (1995): 19-38. [Orig. in Bulgarian Cyrillic] 